\title{
A Clean Technology for Future Prospective: Emission Modeling of Gas Based Power Plant
}

\author{
Markandeya $^{1,2}$, S. P. Shukla1, G. C. Kisku ${ }^{2 *}$ \\ ${ }^{1}$ Department of Civil Engineering, Institute of Engineering and Technology, Lucknow, India \\ ${ }^{2}$ Environmental Monitoring Laboratory, Environmental Toxicology Group, CSIR-Indian Institute of Toxicology Research (CSIR-IITR), \\ Lucknow, India \\ Email: *kiskugc1@rediffgmail.com
}

How to cite this paper: Markandeya, Shukla, S.P. and Kisku, G.C. (2016) A Clean Technology for Future Prospective: Emission Modeling of Gas Based Power Plant. Open Journal of Air Pollution, 5, 144-159. http://dx.doi.org/10.4236/ojap.2016.54011

Received: August 5, 2016

Accepted: December 4, 2016

Published: December 7, 2016

Copyright $\odot 2016$ by authors and Scientific Research Publishing Inc. This work is licensed under the Creative Commons Attribution International License (CC BY 4.0).

http://creativecommons.org/licenses/by/4.0/

\section{(c) (i) Open Access}

\begin{abstract}
The aim of present research is to study the dispersion of air pollutants using the air quality model, AERMOD and to predict the impact of pollutants $\left(\mathrm{PM}_{10}, \mathrm{NO}_{2}\right.$ and $\mathrm{CO})$ at the receptor level released from Gas Based Power Plant (GBPP). The netconcentrations including monitored data plus predicted values of $\mathrm{PM}_{10}, \mathrm{NO}_{2}$ and $\mathrm{CO}$ would be increased from base value 75 to $77.61 \mu \mathrm{g} / \mathrm{m}^{3}$ with an increase of $3.48 \%, 22$ to $26.66 \mu \mathrm{g} / \mathrm{m}^{3}$ with an increase of $21.18 \%$ and 428 to $538.37 \mu \mathrm{g} / \mathrm{m}^{3}$ with an increase of $25.79 \%$ respectively. The study of hill effect showed that it had profound impact upon the dispersion of pollutants and the ratio (with hill and without hill) of each pollutant was 3.89 for $\mathrm{PM}_{10}(24 \mathrm{hr}), 2.40$ for $\mathrm{NO}_{2}(24 \mathrm{hr})$ and 13.98 for $\mathrm{CO}(1 \mathrm{hr})$. The natural gas based plant not only decreases the pollution level but also reduces the hospital treatment cost and protects the public health. The modeling results suggest that the GBPP could be a clean technology as replacement of coal power plants located in the city which pollute the environment considerably in spite of control measures installed.
\end{abstract}

\section{Keywords}

Gas Based Power Plant, AERMOD, Fine Particulates and Gaseous Pollutants, Health Effects

\section{Introduction}

Industrial activities are continuously releasing huge amounts of health affecting air pollutants which can jeopardise the environmental health and impair the balance of the 
ecosystem. These air pollutants formed in the atmosphere gradually come down and concentrate in the breathing zone or are deposited on the ground level under gravitational pool [1]. All environmental receptors, including plant and animal life are severely affected, eventually resulting in their death [2] [3]. Many Air Quality Models (AQMs) have been developed over the years to predict the atmospheric build-up of pollutants and to determine the ground level concentration, which are likely to affect property and life [2]. These air pollutants can directly be measured qualitatively and quantitatively by various chemical methods. But recently mathematical models have become more popular and reliable tools to predict the ground level concentration of air pollutants at selected location in downwind direction. These modern and sophisticated AQMs provide the exposure level in any particular direction and distance from the point sources at different heights [3]. Such AQMs are widely used because of their cost effectiveness and ease of operation as compared to actual field survey for the proper management of the impact of pollutant emissions on the environment.

These models also provide many micro details in advance regarding the rate of transport, rate of transformation from one chemical form to another in the atmosphere depending upon the prevailing climatic conditions, vertical/horizontal turbulence and diffusion/dispersal of pollutants and gravitational settling of pollutants [4]. AQMs in general, use the meteorological data, stack configurations (stack elevation from the ground level, stack height, effective stack height, stack inner diameter at exit point, flue gas discharge velocity and stack gas temperature), type of raw materials, process technology, chemical reaction in the atmosphere, terrain topology and topography especially the altitude of nearby hills and nature of valley as well as ambient air related parameters for the assessment of the dispersion of air pollutants [5].

Fragmented information is put together for simulation through complex mathematical calculations using permutation and combinations by the AQMs. These models produce valuable information which is likely to occur at different situations or different seasons viz. summer or winter [6] [7]. Based on these predictions, preventive measures could be taken in advance to reduce the magnitude or to dilute the effects so that deleterious effects upon human/animal life, property, flora and fauna, terrestrial/aquatic ecology can be avoided. Land and natural resources could be conserved from further degradation [8].

The atmospheric build-up of hazardous air pollutants may result in fog formation in a location especially valley of a hilly region. It is due to the poor atmospheric stability conditions like thermal inversion and extremely stable condition. They have become a frequent phenomenon adversely affecting flora and fauna of the surrounding environment [8] [9].

The main objective of this modeling study therefore, is to estimate the potential of air emissions from a gas based power plant (GBPP) and to determine the maximum ground level concentration of particulate matter $\left(\mathrm{PM}_{10}\right)$, carbon monoxide $(\mathrm{CO})$ and nitrogen dioxide $\left(\mathrm{NO}_{2}\right)$ on the existing air quality and its negative effect on surrounding environment. 


\section{Materials and Methods}

\subsection{Monitoring of Particulate Matters $\left(\mathrm{PM}_{10} \& \mathrm{PM}_{2.5}\right)$ and Gaseous Pollutants $\left(\mathrm{SO}_{2}, \mathrm{NOx} \& \mathrm{CO}\right)$}

\subsubsection{Sampling Location and Frequency}

Three locations taken average of each was selected and monitored to determine the concentrations of existing air quality of plant area which was considered for further calculations. The sampling frequency was twice in a month for $24 \mathrm{hr}$.

\subsubsection{Sampling Procedures}

Particulate Matters: Particulate Matters $\left(\mathrm{PM}_{10}\right.$ and $\left.\mathrm{PM}_{2.5}\right)$ are the two major components of inhalable particles which are targeted in this investigation. Respirable Dust Sampler (APM 460, Envirotech, New Delhi) was operated at a flow rate of $1.1 \mathrm{~m}^{3} / \mathrm{min}$. The particles $\leq 10 \mu \mathrm{m}$ in size were separated from non-respirable coarse particles by centrifugal force, collected on the EPM 2000 filter, 8" $\times 10$ " (Whatman), previously conditioned at $70^{\circ} \mathrm{C}-80^{\circ} \mathrm{C}$ were determined gravimetrically [10]. Simultaneously, the monitoring of $\mathrm{PM}_{2.5}$ was carried out using Fine Particulate Sampler (APM 550) fitted with a WINS-Anderson Impactor, Envirotech, New Delhi and was operated at a constant flow rate of $16.6 \mathrm{~L} / \mathrm{min}$. In $\mathrm{PM}_{2.5}$ sampler, the air stream leaving the WINS cascade impactor consists of only fine particulates with an aerodynamic diameter $\leq 2.5 \mu \mathrm{m}$. Teflon filters $(47 \mathrm{~mm})$ were used for gravimetric analysis of $\mathrm{PM}_{2.5}$ [11] [12]. Samplers were always installed at a height of 4 feet above the ground level to collect representative particulates present in the breathing zone.

Sulphur Dioxide: The best method currently available for $\mathrm{SO}_{2}$ analysis is the modified West-Gaeke method. It can measure concentrations over a range of $0.005-5.000$ ppm with an accuracy of $\pm 10 \%$ (including sampling and analysis) at the lower end of the range and $\pm 5 \%$ at the upper end with a precision of about $2 \%$. In this method, a known quantity of air was passed for $8 \mathrm{hr}$ through an impinger containing known quantity of absorbing solution, sodium tetra chloro mercurate $\left(\mathrm{NaHgCl}_{4}\right)$. The absorbed sample and solution forms a stable color complex of di-chloro sulphito mercurate with p-rosaniline hydrochloride. The intensity of color developed was estimated by a spectrophotometer at $560 \mathrm{~nm}$ using a calibration curve.

Oxides of Nitrogen: A known quantity of air was bubbled for $8 \mathrm{hr}$ through an impinger containing $\mathrm{NaOH}$ solution as absorbing media which formed a stable solution of sodium nitrate. The nitrite ion produced during sampling was determined colorimetrically at $540 \mathrm{~nm}$ by reading the exposed absorbing chemical solution with phosphoric acid, sulphanilamide and N-(1-Napthyl) ethylene di-amine di-hydrochloride following the modified Jacob and Hochheiser method.

Carbon Monoxide: Online CO analyzer was used to continuous monitoring of CO. This equipment works on Non-Dispersive Infrared (NDIR) spectroscopy. NDIR photometry provides a method of utilizing of integrated absorption of infra-red energy over most of the spectrum for a given compound to provide a quantitative determination of concentration of $\mathrm{CO}$ in ambient air. 


\subsection{Description of Model-AERMOD}

All AQMs are developed using the mathematical formulae and statistics to measure the atmospheric build up and dispersal of pollutants released from a source. AERMOD modeling software version 6.6 developed by the United State Environmental Protection Agency (USEPA) in conjunction with American Meteorological Society (AMS) has been used for point source emission. It is commonly known as AMS-USEPA regulatory model or AERMOD. It takes into account the terrain topology, boundary layer and meteorological data to model pollutants transport and dispersion to calculate the temporally averaged air pollution concentrations [12] [13].

\subsection{Model Input}

\subsubsection{Source Characteristics}

The AERMOD modeling system requires a physical description of the ground surface i.e. topography and topology of the surface area. Plant has one stack and its parameters are presented in Table 1.

\subsubsection{Land Use and Geo-Physical Parameters}

The geo-physical parameters are land use pattern, terrain topology, surface roughness, albedo and bowen ratio (Table 2). The NED data was processed with AERMAP, a pre-processor program which was developed to process terrain data (with base elevation and hill height) in conjunction with a layout of receptors and sources to be used in AERMOD [14] [15]. This study model was run with elevations and without elevations to understand the impact of hills.

\subsubsection{Meteorological Data}

The AERMOD modeling system requires a meteorological data like wind speed, wind

Table 1. Model input related to stack, pollutants emission rate and fuel.

\begin{tabular}{ccc}
\hline S. No. & Parameters & Type/Value \\
\hline 1 & Fuel & Natural Gas \\
2 & Stack number & One (1) \\
3 & Stack height & $60 \mathrm{~m}$ \\
4 & Stack diameter & $6.9 \mathrm{~m}$ \\
5 & Stack gas velocity & $19 \mathrm{~m} / \mathrm{s}$ \\
6 & Stack exit gas flow rate & $2560 \times 10^{3} \mathrm{~m} / \mathrm{hr}$ \\
7 & Flue gas temperature & $95^{\circ} \mathrm{C}$ \\
8 & Emission rate of PM & $8.7 \mathrm{~kg} / \mathrm{hr}$ \\
9 & Emission rate of CO & $36.5 \mathrm{~kg} / \mathrm{hr}$ \\
10 & Emission rate of NOx & $99.8 \mathrm{~kg} / \mathrm{hr}$ \\
11 & Emission rate of SOx & Nil (no sulphur in the fuel)
\end{tabular}


Table 2. Land use and geo-physical patterns of the study area.

\begin{tabular}{ccc}
\hline S. No. & Geo-physical Parameter & Characteristic/Value \\
\hline 1 & Land use & Rural, Fellow land \\
2 & Albedo $^{*}$ & 0.24 \\
3 & Bowen Ratio $^{* *}$ & 0.89 \\
4 & Surface Roughness & 0.91 \\
\hline
\end{tabular}

${ }^{*}$ Albedo is defined as the ratio of diffusely reflected to incident electromagnetic radiation. ${ }^{* *}$ The Bowen ratio is the mathematical method generally used to calculate heat lost (or gained) in a substance; it is the ratio of energy fluxes from one state to another by sensible and latent heating respectively.

direction, ambient air temperature, relative humidity, atmospheric pressure, rainfall, solar radiation, cloud cover, mixing height (the maximum level to which a parcel of air will rise under a given set of conditions) and others. Auto Weather Station (Envirotech, New Delhi) was set up for collection of meteorological data.

\section{Results and Discussion}

The particulate concentrations $\left(\mathrm{PM}_{10}\right.$ and $\left.\mathrm{PM}_{2.5}\right)$ in the ambient air ranged from 49.3 64.8 (avg. $57.0 \pm 5.1) \mu \mathrm{g} / \mathrm{m}^{3}$ and $7.6-24.6$ (avg. $\left.15.9 \pm 5.5\right) \mu \mathrm{g} / \mathrm{m}^{3}$ respectively. Amongst the gaseous pollutants, $\mathrm{SO}_{2}$ ranged from $4.6-7.2$ (avg. $6.2 \pm 0.9$ ) $\mu \mathrm{g} / \mathrm{m}^{3}, \mathrm{NO}_{2}$ ranged from $8.2-23.2$ (avg. $14.2 \pm 4.6) \mu \mathrm{g} / \mathrm{m}^{3}$ and $\mathrm{CO}$ ranged from $0.3-0.5$ (avg. $0.4 \pm 0.1$ ) $\mathrm{mg} / \mathrm{m}^{3}$. The regression $\beta$ coefficient and coefficient of determinant $\mathrm{R}^{2}$ revealed that there were significant effects of temperature and relative humidity on $\mathrm{NO}_{2}$ where as on $\mathrm{PM}_{2.5}$; vapour pressure has positive effect Table 3.

A Wind Rose (WR) gives a succinct graphical view of wind speed and wind direction distributed at a particular location. To draw 16 sectors WR, Wave Lake software was used to process hourly data of wind speed and wind direction. WR diagram and wind class frequency distributions are shown in Figure 1 and Table 4. WR Plot was prepared utilizing data of 6 wind classes and orientation of flow vector (Blowing From). The calm wind i.e. wind speed $\leq 0.5 \mathrm{~m} / \mathrm{sec}$ was $1.61 \%$ which is considered as atmospheric stable condition and unfavourable for dispersion of pollution. Based on speed; wind data were grouped into 6 different classes of $0.5-2.1 \mathrm{~m} / \mathrm{s}$ (10.3\%), $2.1-3.6 \mathrm{~m} / \mathrm{s}(21.4 \%)$, $3.6-5.7 \mathrm{~m} / \mathrm{s}$ (56.8\%), $5.7-8.8 \mathrm{~m} / \mathrm{s}(9.5 \%), 8.8-11.1 \mathrm{~m} / \mathrm{s}(0.3 \%)$ and $\geq 11.1 \mathrm{~m} / \mathrm{s}(0.0 \%)$. The dominant classes of wind speed were $3.6-5.7 \mathrm{~m} / \mathrm{s}$ for $56.8 \%$ followed by $2.1-3.6$ $\mathrm{m} / \mathrm{s}$ for $21.4 \%$. The pre-dominant wind directions were from North-West to South-East and West to East directions.

\subsection{Evaluation of Dispersion Modeling Output}

The modeling was carried out with both terrain options: 1) flat land (considering zero elevation) and 2) Elevated land (considering the hill heights). By this approach, the magnitude of impact of hills was measured. The predicted ambient air concentrations for $\mathrm{PM}_{10}, \mathrm{NO}_{2}$ and $\mathrm{CO}$ were estimated for various averaging periods (24 hr and annual) 
for $\mathrm{PM}_{10}$ and $\mathrm{NO}_{2}$ whereas $1 \mathrm{hr}$ and annual for $\mathrm{CO}$. The predicted highest value of each average period was compared with the standard of NAAQS [16].

\subsubsection{Predicted Value of Particulate Matter $\left(\mathrm{PM}_{10}\right)$}

The model computed concentrations for $\mathrm{PM}_{10}$ are mentioned in Table 5. For elevated terrain (with hills), the highest concentration was $2.61 \mu \mathrm{g} / \mathrm{m}^{3}$ for $24 \mathrm{hr}$ and it was 0.24 $\mu \mathrm{g} / \mathrm{m}^{3}$ for annual. Both these concentrations were found well below the standards of

Table 3. Effect of ambient air temperature, vapour pressure and relative humidity on pollutants.

\begin{tabular}{ccccccc}
\hline \multirow{2}{*}{ Pollutants } & \multicolumn{2}{c}{ Temperature } & \multicolumn{2}{c}{ Vapour pressure } & \multicolumn{2}{c}{ Relative humidity } \\
\cline { 2 - 6 } & $\beta$ value & $\mathrm{R}^{2}$ & $\beta$ value & $\mathrm{R}^{2}$ & $\beta$ value & $\mathrm{R}^{2}$ \\
\hline $\mathrm{PM}_{10}$ & 0.73 & 0.2 & 0.42 & 0.21 & 0.42 & 0.35 \\
$\mathrm{PM}_{2.5}$ & 0.28 & 0.03 & 0.90 & 0.77 & 0.15 & 0.04 \\
$\mathrm{SO}_{2}$ & 0.11 & 0.14 & 0.05 & 0.09 & 0.06 & 0.03 \\
$\mathrm{NO}_{2}$ & 0.99 & 0.44 & 0.33 & 0.14 & 0.46 & 0.46 \\
$\mathrm{CO}$ & 0.01 & 0.01 & 0.01 & 0.11 & 0.03 & 0.07 \\
\hline
\end{tabular}

Table 4. Frequency distribution (\%) of wind speed (m/s) and wind direction.

\begin{tabular}{|c|c|c|c|c|c|c|c|}
\hline \multirow{2}{*}{$\begin{array}{l}\text { Wind Direction } \\
\text { (Blowing From) }\end{array}$} & \multicolumn{7}{|c|}{ Classes of Wind Speed } \\
\hline & $0.5-2.1$ & $2.1-3.6$ & $3.6-5.7$ & $5.7-8.8$ & $8.8-11.1$ & $\geq 11.1$ & Total \\
\hline $348.7-11.2(\mathrm{E})$ & 0.6 & 1.1 & 1.4 & 0 & 0.0 & 0.0 & 3.1 \\
\hline 11.2 - 33.7 (NEE) & 0.6 & 0.6 & 1.0 & 0 & 0.0 & 0.0 & 2.1 \\
\hline 33.7 - $56.2(\mathrm{NNE})$ & 0.7 & 1.1 & 5.1 & 0.1 & 0.0 & 0.0 & 7.0 \\
\hline 56.2 - 78.7 (NEN) & 0.6 & 1.3 & 3.1 & 0.3 & 0.0 & 0.0 & 5.4 \\
\hline $78.7-101.2(\mathrm{~N})$ & 1.1 & 2.2 & 2.4 & 0.4 & 0.0 & 0.0 & 6.0 \\
\hline 101.2 - $123.7(\mathrm{NNW})$ & 1.2 & 1.7 & 1.2 & 0.3 & 0.0 & 0.0 & 4.4 \\
\hline $123.7-146.2(\mathrm{NW})$ & 0.9 & 0.5 & 0.2 & 0.0 & 0.0 & 0.0 & 1.6 \\
\hline 146.2 - 168.7 (NWW) & 0.2 & 0.0 & 0.0 & 0.0 & 0.0 & 0.0 & 0.3 \\
\hline $168.7-191.2(\mathrm{~W})$ & 0.3 & 0.1 & 0.0 & 0.0 & 0.0 & 0.0 & 0.4 \\
\hline 191.2 - 213.7 (WWS) & 0.3 & 0.2 & 0.3 & 0.0 & 0.0 & 0.0 & 0.8 \\
\hline 213.7 - 236.2 (WS) & 0.4 & 1.0 & 1.9 & 0.5 & 0.1 & 0.0 & 3.9 \\
\hline $236.2-258.7$ (WSS) & 0.5 & 2.1 & 9.1 & 2.3 & 0.1 & 0.0 & 14.0 \\
\hline $258.7-281.2(\mathrm{~S})$ & 0.9 & 3.5 & 8.3 & 2.2 & 0.1 & 0.0 & 14.9 \\
\hline 281.2 - 303.7 (SSE) & 0.6 & 2.6 & 8.0 & 0.8 & 0.1 & 0.0 & 12.0 \\
\hline 303.7 - 326.2 (SE) & 0.7 & 2.2 & 10.4 & 1.6 & 0.0 & 0.0 & 14.9 \\
\hline 326.2 - 348.7 (SEE) & 0.7 & 1.4 & 4.3 & 0.9 & 0.0 & 0.0 & 7.3 \\
\hline Total & 10.3 & 21.4 & 56.8 & 9.5 & 0.3 & 0.0 & 98.4 \\
\hline
\end{tabular}

Frequency of calm wind (wind velocity $\leq 0.5 \mathrm{~m} / \mathrm{s}$ ): $1.64 \%$, Average wind speed: $4.04 \mathrm{~m} / \mathrm{s}$. 


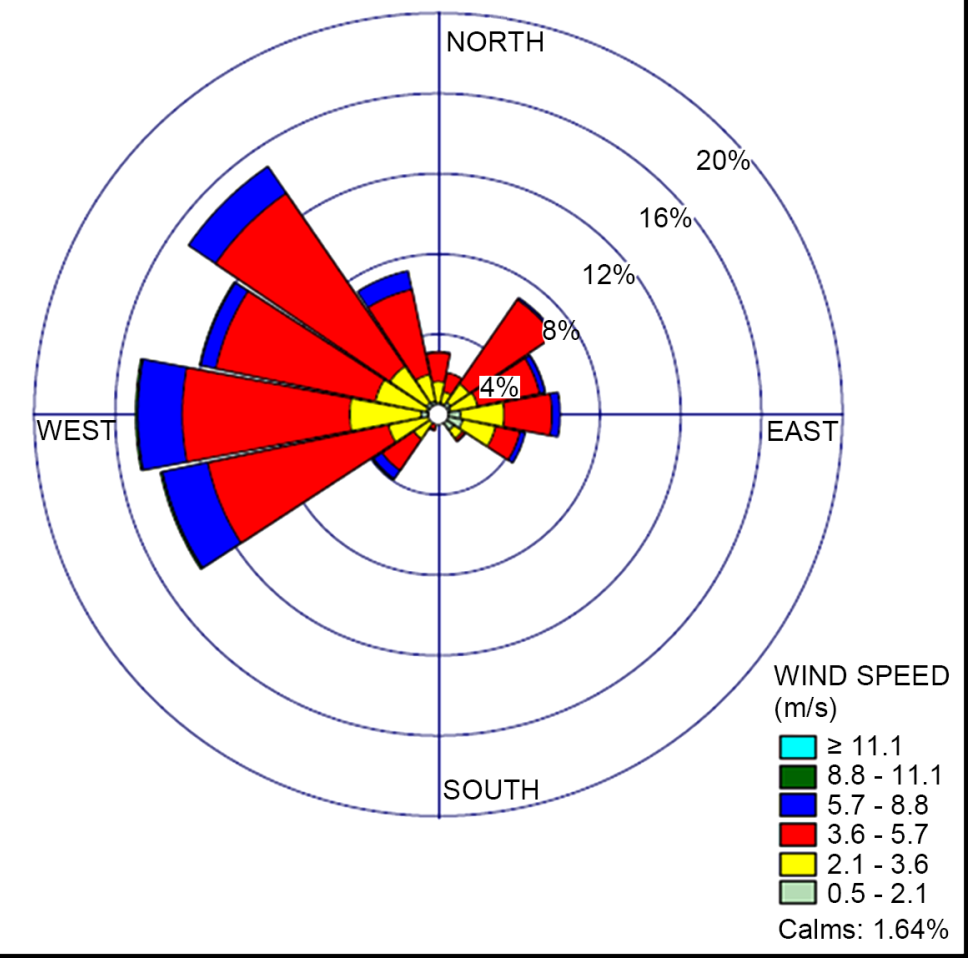

(a)

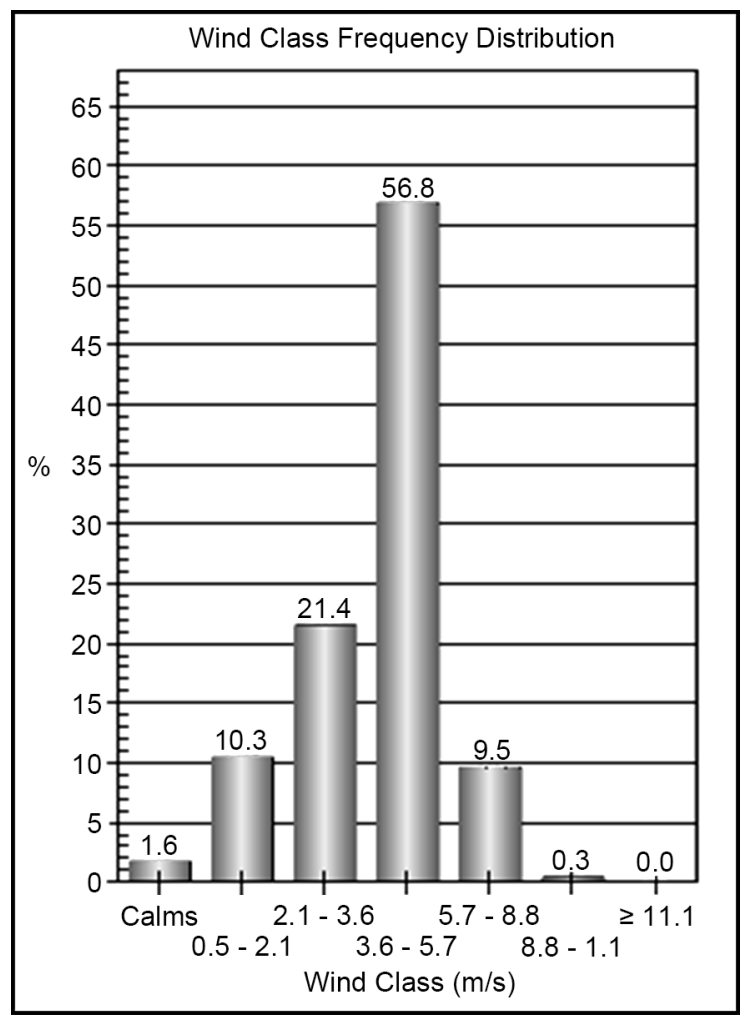

(b)

Figure 1. (a) Wind Rose plots and (b) Histogram of wind class frequency distribution.

Table 5. Model-computed CO concentration $\left(\mu \mathrm{g} / \mathrm{m}^{3}\right)$ with and without hill elevation.

\begin{tabular}{|c|c|c|c|c|c|c|c|c|c|c|c|c|}
\hline & \multicolumn{6}{|c|}{ Concentration with Hill } & \multicolumn{6}{|c|}{ Concentration without Hill } \\
\hline & \multicolumn{2}{|c|}{$\mathrm{PM}_{10}$} & \multicolumn{2}{|c|}{$\mathrm{NO}_{2}$} & \multicolumn{2}{|c|}{$\mathrm{CO}$} & \multicolumn{2}{|c|}{$\mathrm{PM}_{10}$} & \multicolumn{2}{|c|}{$\mathrm{NO}_{2}$} & \multicolumn{2}{|c|}{$\mathrm{CO}$} \\
\hline 1 & 2.61 & 0.24 & 4.66 & 0.65 & 110.37 & 0.90 & 0.67 & 0.08 & 1.94 & 0.26 & 7.89 & 0.32 \\
\hline 3 & 2.28 & 0.2 & 4.51 & 0.59 & 106.54 & 0.81 & 0.60 & 0.06 & 1.55 & 0.24 & 7.41 & 0.26 \\
\hline
\end{tabular}

NAAQS (Standard: for $24 \mathrm{hr} 100 \mu \mathrm{g} / \mathrm{m}^{3}$ and for annual $60 \mu \mathrm{g} / \mathrm{m}^{3}$ ). The individual highest concentrations for $24 \mathrm{hr}$ and annual are shown in isopleths (Figure 2 and Figure 3 ).

\subsubsection{Predicted Value of Nitrogen Dioxide $\left(\mathrm{NO}_{2}\right)$}

The model-computed concentrations for $\mathrm{NO}_{2}$ are given in Table 5. During the modeling for $\mathrm{NO}_{2}$, the plume volume molar ratio method was considered. The ambient equilibrium ratio $\mathrm{NO}_{2} / \mathrm{NOx}$ was taken as 0.90 . When the hill height was taken into consideration, the highest predicted value of $\mathrm{NO}_{2}$ was $4.7 \mu \mathrm{g} / \mathrm{m}^{3}$ for $24 \mathrm{hr}$ as compared to 1.94 $\mu \mathrm{g} / \mathrm{m}^{3}$ without considering the hill height. The observed concentrations were found below the NAAQS for $\mathrm{NO}_{2}$ (Standard: for $24 \mathrm{hr} 80 \mu \mathrm{g} / \mathrm{m}^{3}$ and for annual $40 \mu \mathrm{g} / \mathrm{m}^{3}$ ). The 

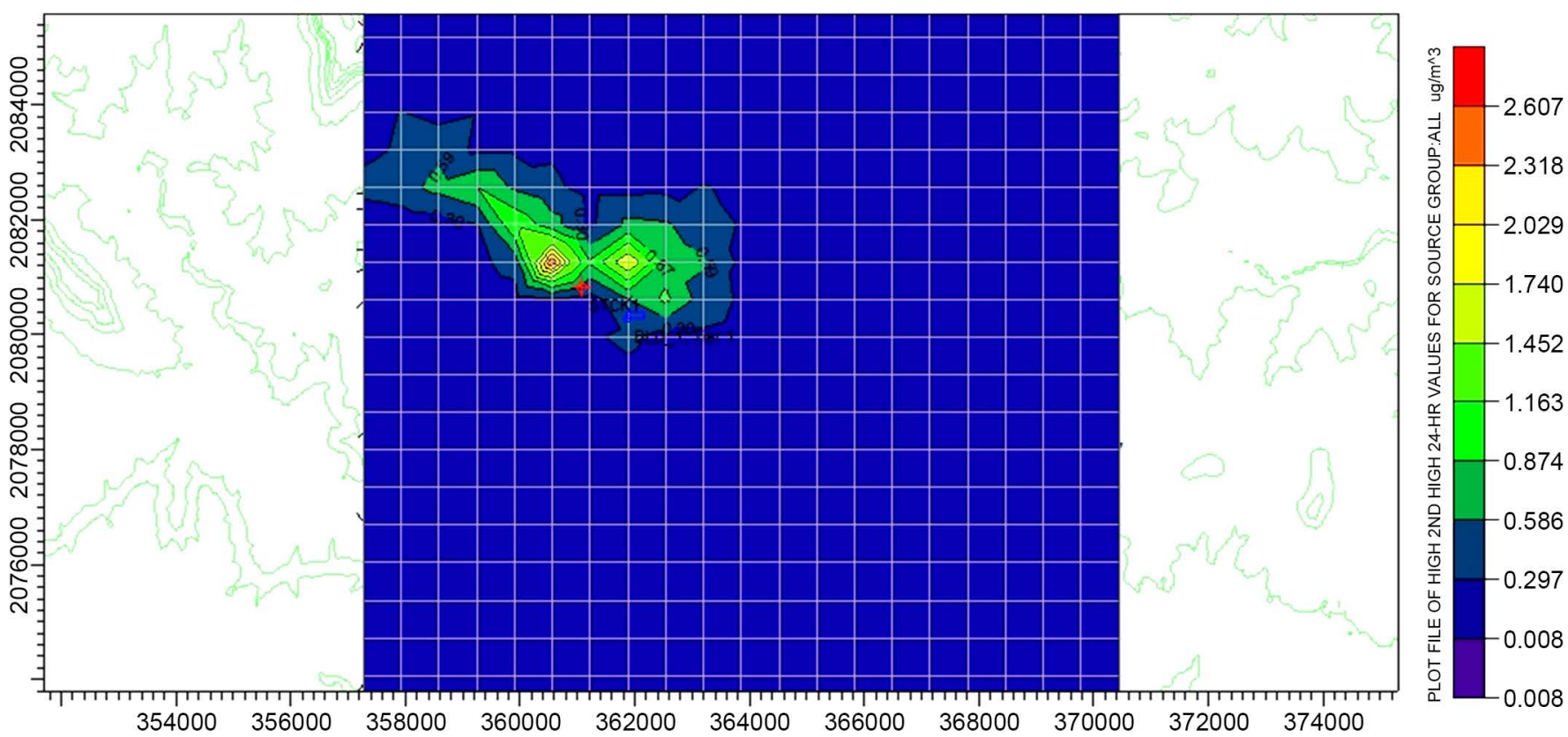

Figure 2. Isopleth of $\mathrm{PM}_{10}$ concentration for $24 \mathrm{hr}$ average.
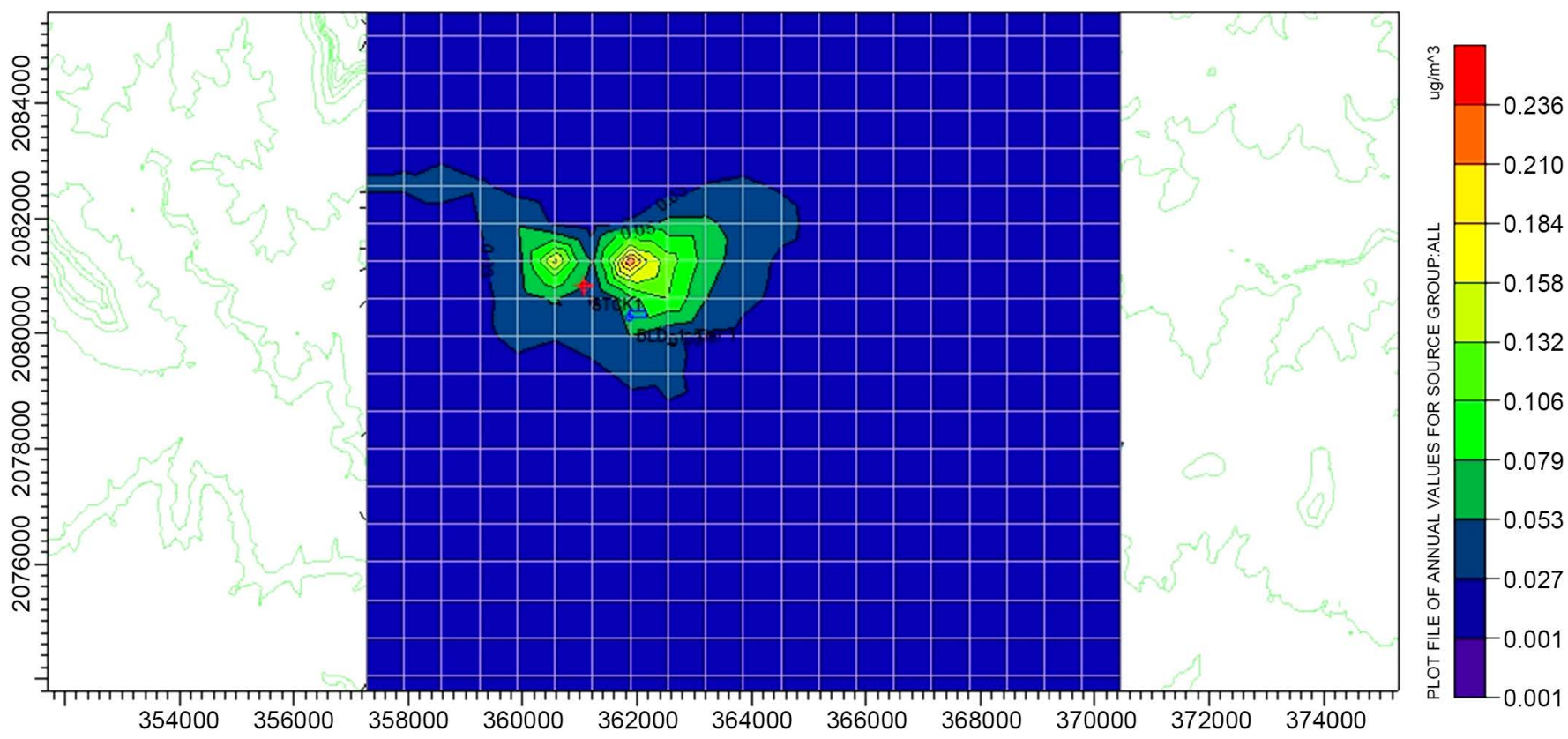

Figure 3. Isopleth of $\mathrm{PM}_{10}$ concentration for annual.

individual highest concentrations for $24 \mathrm{hr}$ and annual are shown in isopleths (Figure 4 and Figure 5).

\subsubsection{Predicted Value of Carbon Monoxide (CO)}

The model computed concentrations for $\mathrm{CO}$ are given in Table 5. When the hill height is taken into consideration, the highest predicted values of $\mathrm{CO}$ were $110.37 \mu \mathrm{g} / \mathrm{m}^{3}$ for 1 $\mathrm{hr}$ and $0.90 \mu \mathrm{g} / \mathrm{m}^{3}$ for annual. The concentration of carbon monoxide for $1 \mathrm{hr}$ was 


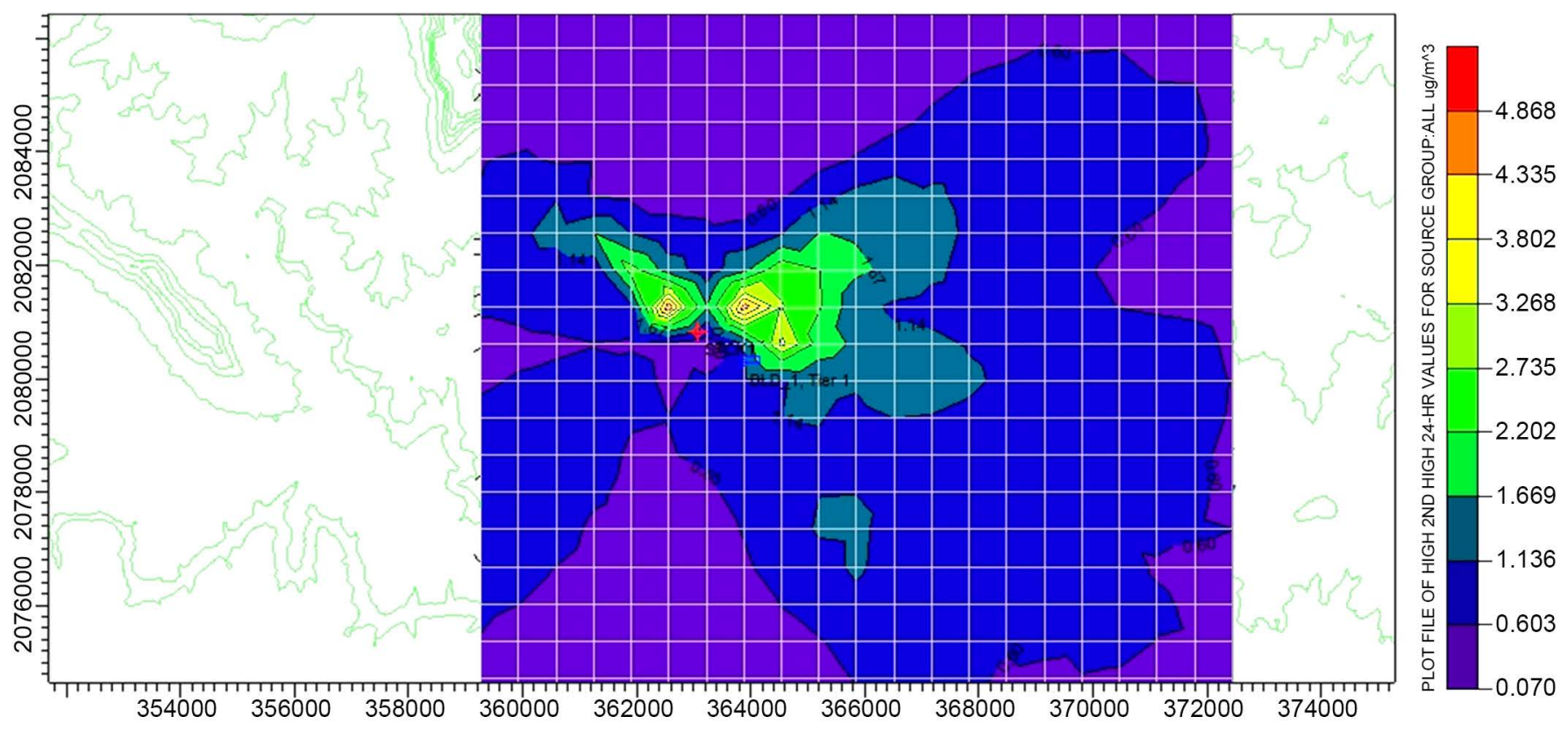

Figure 4. Isopleth of $\mathrm{NO}_{2}$ concentration for $24 \mathrm{hr}$ average.

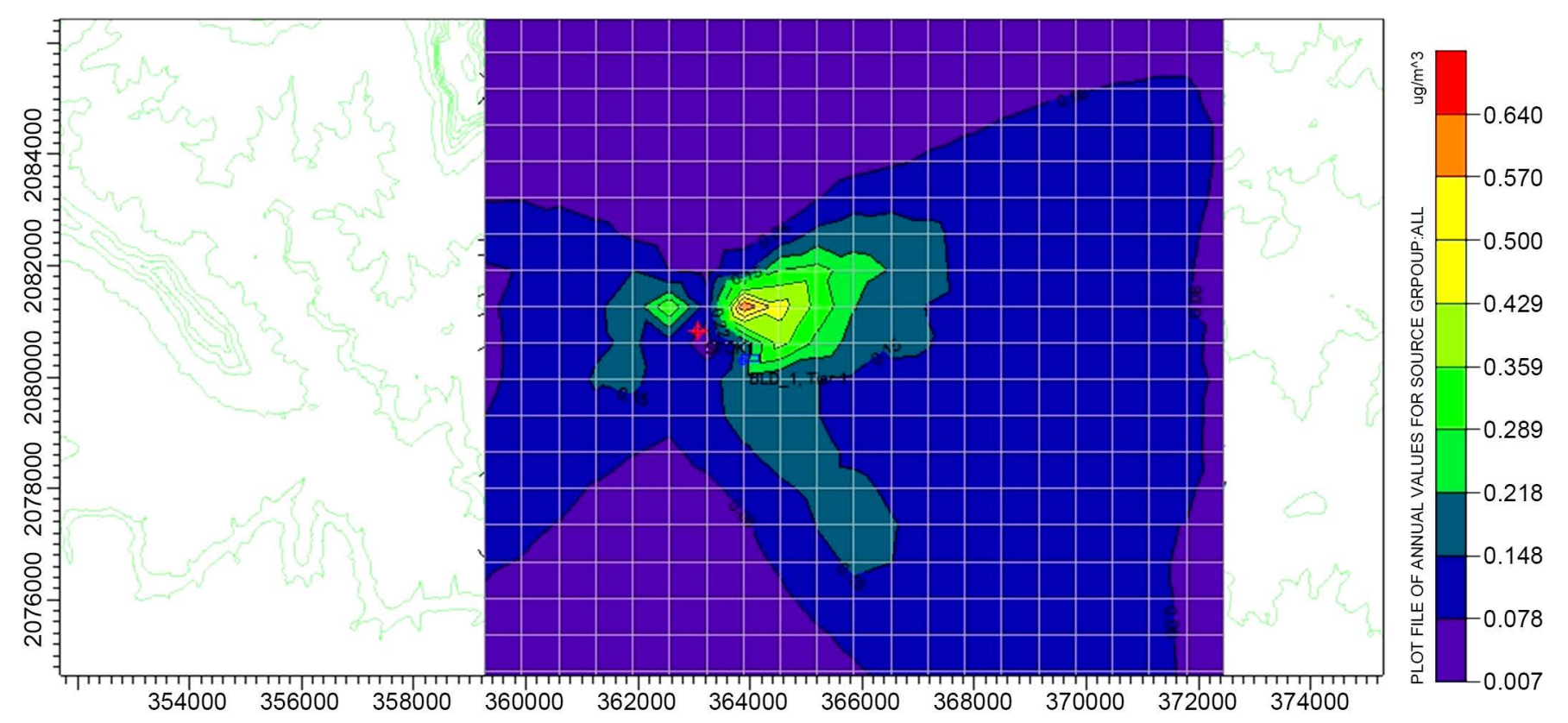

Figure 5. Isopleth of $\mathrm{NO}_{2}$ concentration for annual.

found to be below the NAAQS for CO (Standard: for $1 \mathrm{hr} 4 \mathrm{mg} / \mathrm{m}^{3}$ ). The isopleths related to highest values for $1 \mathrm{hr}$ and annual at receptor locations are shown in Figure 6 and Figure 7 respectively.

The higher concentration of particulate matter $\left(\mathrm{PM}_{10}\right)$ with respect to gaseous pollutants was found to be within the plant boundary area as compared to the outside area. This may be attributed to higher mass and density of particulate matter than gaseous pollutants; therefore particulate matter cannot disperse easily with time. Because of the 


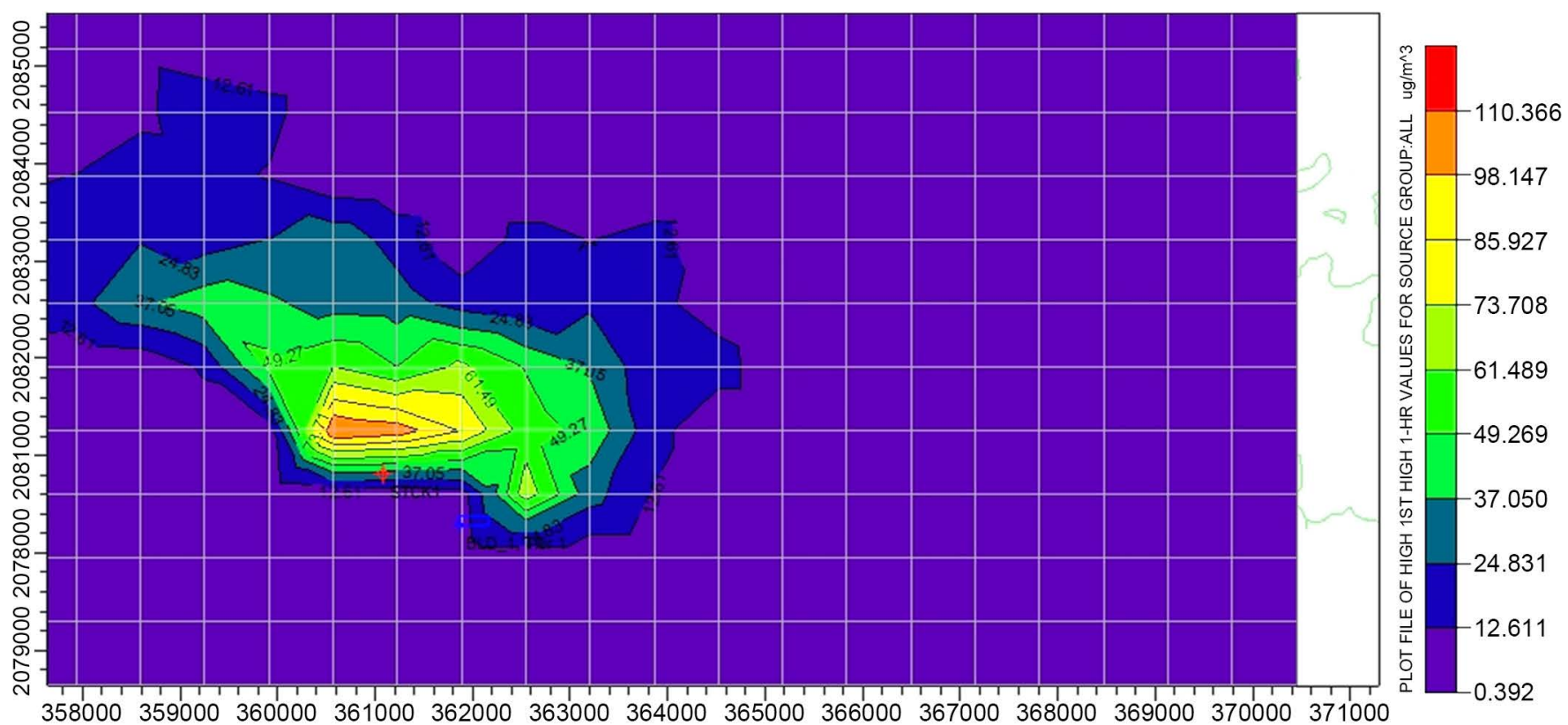

Figure 6. Isopleth of CO concentration for $1 \mathrm{hr}$ average.
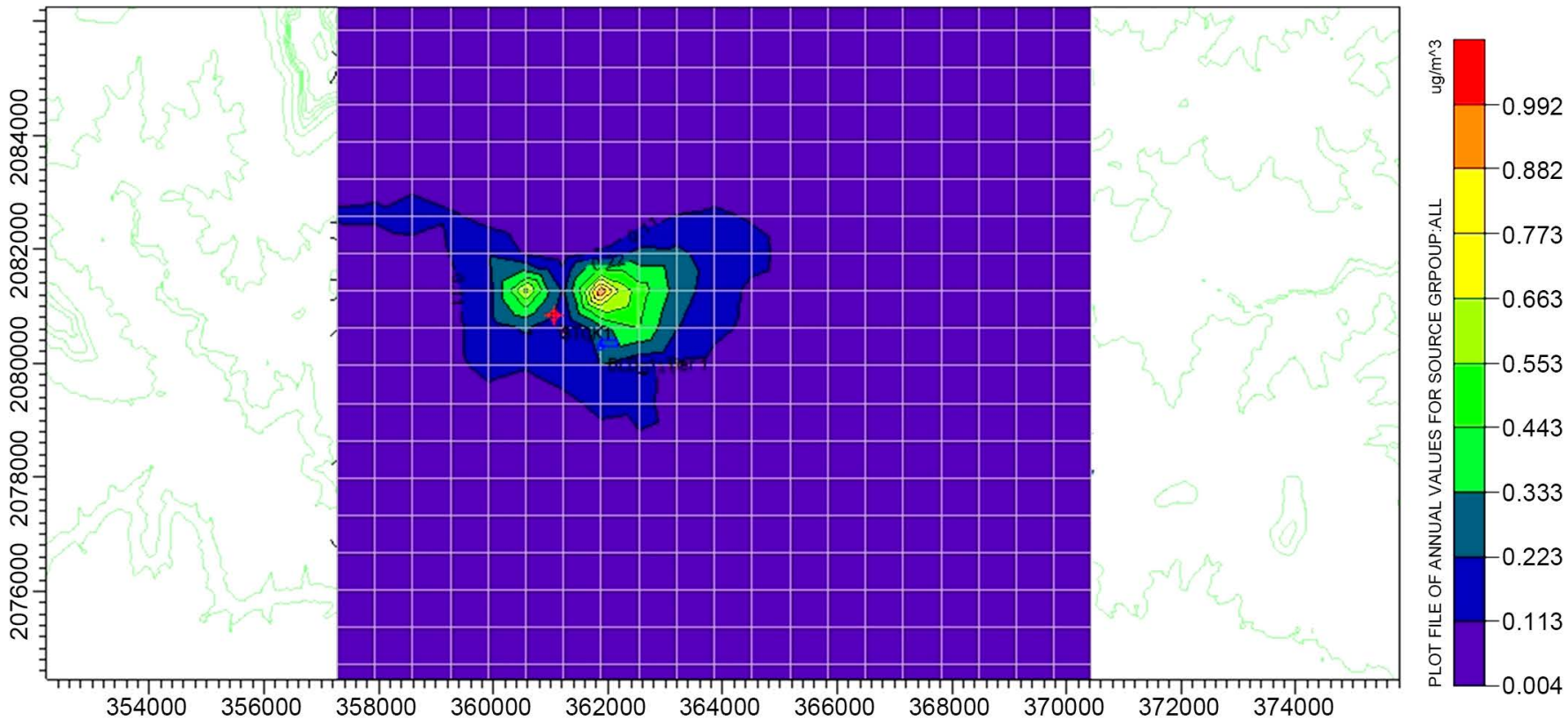

Figure 7. Isopleth of CO concentration for annual.

same reason, there is a tendency of fallout of particulates $\left(\mathrm{PM}_{10}\right)$ within $2-3 \mathrm{~km}$ from the source (stack) but gaseous pollutants may disperse in large area i.e. trans-boundary in nature.

It is evident from the isopleth shown in Figure 2 that the highest concentration of particulate matter- $\mathrm{PM}_{10}$ was within the plant boundary in North-East direction. The annually dispersion of $\mathrm{PM}_{10}$ was in East (Figure 3). It is clear from the isopleth shown in Figure 6 that the higher concentration $\left(110.37 \mu \mathrm{g} / \mathrm{m}^{3}\right)$ of carbon monoxide for $1 \mathrm{hr}$ 
was found in area close to stack and the dispersion of carbon monoxide were in East direction (Figure 7).

\subsection{Impact of Hill upon Dispersion of Pollutants}

Since the plant is situated in the lap of the hills, henceforth it becomes imperative to carry out AERMOD to study the effect of hills upon dispersion of pollutants. The annual concentrations of $\mathrm{PM}_{10}, \mathrm{NO}_{2}$ and $\mathrm{CO}$ with hill were $0.24,0.65$ and $0.90 \mu \mathrm{g} / \mathrm{m}^{3} \mathrm{re}$ spectively while their corresponding values were $0.08,0.26$ and 0.32 respectively without hill. The percentage increase due to the presence of hills was $26 \%$ for $\mathrm{PM}_{10}, 42 \%$ for $\mathrm{NO}_{2}$ and $7 \%$ for CO. The ratio (with hill and without hill) of each pollutant was 3.89 for $\mathrm{PM}_{10}(24 \mathrm{hr}), 2.40$ for $\mathrm{NO}_{2}(24 \mathrm{hr})$ and 13.98 for $\mathrm{CO}(1 \mathrm{hr})$ while the annual ratio (with hill and without hill) was 3.00 for $\mathrm{PM}_{10}, 2.50$ for $\mathrm{NO}_{2}$ and 2.81 for CO. The ratio denotes the fold increase of pollutants because of hills present in the area. The overall model output for $\mathrm{PM}_{10}, \mathrm{NO}_{2}$ and $\mathrm{CO}$ for averaging periods are summarized in Table 6.

The net-concentrations including monitored data plus predicted value of $\mathrm{PM}_{10}, \mathrm{NO}_{2}$ and CO would be increased from 75 to $77.61 \mu \mathrm{g} / \mathrm{m}^{3}$ with an increase of $3.48 \%, 22$ to $26.66 \mu \mathrm{g} / \mathrm{m}^{3}$ with an increase of $21.18 \%$ and 428 to $538.37 \mu \mathrm{g} / \mathrm{m}^{3}$ with an increase of $25.79 \%$ respectively. These calculated net-concentrations of $\mathrm{PM}_{10}, \mathrm{NO}_{2}$ and $\mathrm{CO}$ are found to be within their prescribed Indian standards of NAAQS.

The highest values obtained from the modeling output for $\mathrm{PM}_{10}, \mathrm{NO}_{2}$ and $\mathrm{CO}$ for each averaging period were compared and found to be below their respective standards of NAAQS. Finally, the model-computed concentrations were superimposed on the monitored data obtained from field survey to calculate the net-concentrations for each pollutant and were compared with their standards. Results suggested that even after consideration of maximum existing pollution levels; the net-concentrations will remain within the limits of NAAQS and thus plant will ensure the compliance of pollution norms.

Table 6. Overall modeling output, monitored GLC and superimposed data with their standards [16].

\begin{tabular}{|c|c|c|c|c|c|c|}
\hline \multicolumn{7}{|c|}{ Concentration in $\mu \mathrm{g} / \mathrm{m}^{3}$} \\
\hline Pollutants & Averaging time & $\begin{array}{l}\text { Monitored GLC } \\
\text { (a) }\end{array}$ & $\begin{array}{l}\text { Model-computed } \\
\text { highest value } \\
\text { (b) }\end{array}$ & $\begin{array}{l}\text { Net-concentration } \\
\qquad(\mathrm{a}+\mathrm{b})\end{array}$ & NAAQS Standard & $\begin{array}{c}\text { Net-concentration } \\
\text { increased in } \% \\
{[(\mathrm{~b} / \mathrm{a}) \times 100]}\end{array}$ \\
\hline $\mathrm{PM}_{10}$ & $24 \mathrm{hr}$ & 75 & 2.61 & 77.61 & 100 & 3.48 \\
\hline \multirow{2}{*}{$\mathrm{NO}_{2}$} & $24 \mathrm{hr}$ & 22 & 4.66 & 26.66 & 80 & 21.18 \\
\hline & Annual & 15 & 0.65 & 15.65 & 40 & 4.33 \\
\hline $\mathrm{CO}$ & $1 \mathrm{hr}$ & 428 & 110.37 & 538.37 & 4000 & 25.79 \\
\hline
\end{tabular}

${ }^{\#}$ Ground Level Concentration. 


\subsection{Pre-Conditions Required for Development of Catastrophe Like Situation}

The more complex the situation a model is required to simulate, the poorer its performance is likely to be. However, AERMOD models will handle complex terrain much more realistically than others. Since plant will be commissioned in undulating terrain and surrounded by many hills; AERMOD to ISCST3 were preferred which consider both downwash and non-downwash. The model was run repeatedly for better predictions to visualize a variety of scenarios that may arise due to sudden change or build up of pollutants in the atmosphere during different climatic conditions and also to nullify the erratic output.

It is not possible to gauge the situation under all the unwanted happenings likely to occur could not be possible to gauge the situation in advance through modeling. Since chimney height is less than the heights of surrounding hills, there is a fair chance of trapping of pollutants released from stack within mixing height and not sufficiently dispersed. Moreover, these dispersed air pollutants may strike back after hitting the surface of hills and accumulate in the valley region. There is one such imaginary catastrophe phenomenon which may appear during winter season when the mixing height $(110 \mathrm{~m})$ is significantly low and other atmospheric conditions are stable. In worst case, when there is continuous drizzling for a few days with blowing of clammy wind $(\leq 0.5$ $\mathrm{m} / \mathrm{s}$ ); the atmospheric air parcel may get saturated with water vapour. The densities of pollutants proportionately increase and become heavier than the air. The buoyancy of pollutants decreases and they slowly come down to the earth's surface. Formation of photochemical smog could not be ruled out during the day time when enough sun rays are available. In such a scenario human, flora and fauna will be affected immensely (Figure 8).

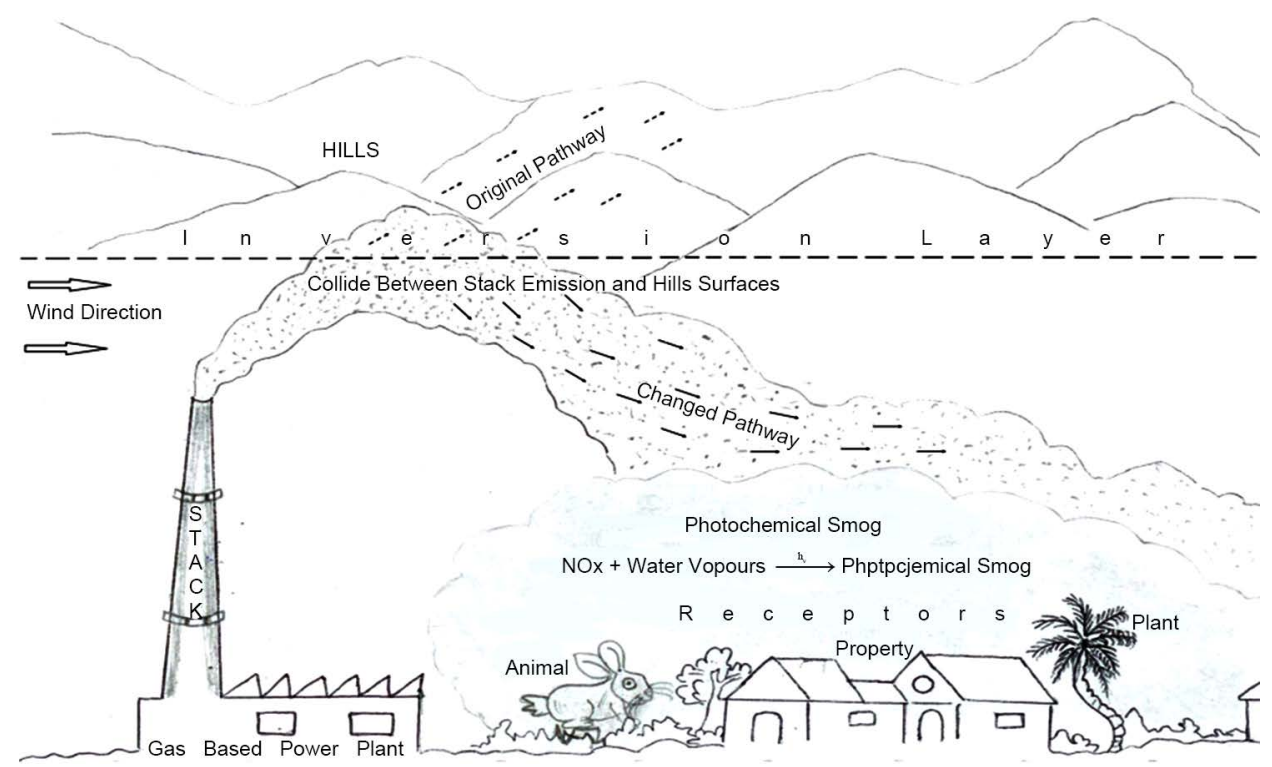

Figure 8. Schematic effects of hills upon dispersal pathway of pollutants and formation of photochemical smog and its impact on receptors. 
The possibility of occurrence of such critical circumstances however, is rare because the life cycle of dumping weather remains usually for only 1 to 2 days in this part whereas at least 3 to 5 days is required to form such a worsening situation. If really such a grave situation happens in reality then plant should be shut down for few days. India is a tropical country and Rajasthan's Thar Desert is nearer to project site. Project area experiences a longer summer season followed by monsoon season. Winter season is comparatively short ranging from 2 to 3 weeks during December to January. Hardly, there is any rainfall during winter season therefore, it is expected that the water vapour in the atmosphere is relatively low. Moreover, as the sun rises, the ambient air temperature becomes normal. The average air temperature is about $16^{\circ} \mathrm{C}$ which can radiate sufficient energy to disperse the accumulated pollutants/fog developed in the night or during wee hours of the day.

\subsection{Possible Harmful Health Effects of Pollutants}

All the three critical health affecting parameters $\left(\mathrm{PM}_{10}\right.$, NOx and $\left.\mathrm{CO}\right)$ have undesirable, asymptomatic and unmeasurable effects on human and environmental health [14]. Entry of pollutants in the human body through inhalation of contaminated air is an important route of exposure [17]. It was reported that higher the levels of $\mathrm{PM}_{10}$, greater the chances for cardiovascular and respiratory diseases (such as asthma, bronchitis, lung cancer) and increased risk of preterm birth. Human exposure to particulate air pollution has long been identified as a risk factor for human mortality and morbidity and many developed countries have amended and implemented the stringent limits for $\mathrm{PM}_{10}$ and other pollutants. Nevertheless, the threshold levels of $\mathrm{PM}_{10}$ at which exposure does not lead to adverse effects on human health have not yet been clearly identified and there is a substantial individual variability in exposure and in the response. It is difficult to establish a particular standard or guideline value that will lead to a complete protection of every individual against all possible cumulative and/or synergistic adverse health effects of fine and ultrafine particles. The effect of fine and ultrafine particles largely depends on the concentration, mass and number, shape and size, load of toxic metals (As, Ni), the composition and concentration of other inorganic and organic pollutants viz. PAHs and bio-aerosols containing pathogenic bacteria, pollen, fungi and various spores [18] [19].

In India, plant burns natural gas which is compared of hydrogen and carbon only. Its produces substantial amount of NOx but it does not emit sulphur dioxide. Normally, nitric oxide (NO), the primary pollutant is discharged by industrial processes and it instantly undergoes chemical reactions in the atmosphere and is converted to NOx. These oxides of nitrogen are the main sources of secondary pollutants of solid aerosols or liquid droplets. Besides, in the lower troposphere, oxides of nitrogen react with other reactive gases and water vapour in the presence of solar energy to form harmful photochemical smog. This smog has often been detected in the urban atmosphere and accumulates in the breathing zone owing to its higher density than air [14].

Carbon monoxide (CO) is a poisonous gas and has 120 times greater affinity than 
oxygen molecule to bind to haem protein of haemoglobin of red blood cells and produce carboxyhaemoglobin ( $\mathrm{COHb}$ ). This $\mathrm{COHb}$ might be the major cause of thrombosis and brain haemorrhage due to shortage of oxygen in brain [20]. Unburned/partially burned hydrocarbons (UBHC) and $\mathrm{CO}$ are strongly associated for black coughing and eye irritation [11].

Although the concentrations of NOx and CO were found to be below their threshold values; there are numerous studies demonstrating that gaseous pollutants cause respiratory diseases even at low concentrations. It is known that there is a link between $\mathrm{NO}_{2}$ and the risk of lung cancer [21] [22].

\section{Conclusions}

From this modeling study, the following inferences may be affirmed that the plant will release notably low concentration of $\mathrm{PM}_{10}, \mathrm{NO}_{2}$ and $\mathrm{CO}$ emissions in the surrounding environment. The net-concentration was found to be $77.61 \mu \mathrm{g} / \mathrm{m}^{3}$ with an increase of $3.48 \%$ for $\mathrm{PM}_{10}, 26.66 \mu \mathrm{g} / \mathrm{m}^{3}$ with an increase of $21.18 \%$ for $\mathrm{NO}_{2}$ and $538.37 \mu \mathrm{g} / \mathrm{m}^{3}$ with an increase of $25.79 \%$ for CO from their baseline data respectively. These observed net-concentrations of $\mathrm{PM}_{10}, \mathrm{NO}_{2}$ and $\mathrm{CO}$ are found to be within the prescribed Indian standards of NAAQS and thus project will certainly ensure the compliance of pollution norms. Modeling results clearly showed that the hills may have a profound impact upon the dispersion of pollutants and the ratio (with hill and without hill) of each pollutant was 3.89 for $\mathrm{PM}_{10}(24 \mathrm{hr}), 2.40$ for $\mathrm{NO}_{2}(24 \mathrm{hr})$ and 13.98 for $\mathrm{CO}(1 \mathrm{hr})$. We assume that there is a possibility of pollutants building up for a short period in the atmosphere because of surrounding hills during winter. It is forecasted from joint study of field survey and AQM modeling that there might be less chance of fog formation and secondary pollutants viz. photochemical smog and ozone. Predicted results suggest that the intensity of adverse impacts likely to occur due to installation of plant is minimal. Natural GBPP not only decreases the pollution level but also reduces the hospital treatment costs and protects the public health. We recommend that clean GBPP could be the best alternative for replacement of polluted functional coal power plants located in urban areas which are causing havoc by creating pollution problems (e.g. Indraprastha in New Delhi).

\section{Acknowledgements}

The authors are grateful to Mr. B.D. Bhattacharji, CSIR-IITR Lucknow for helping us in editing the manuscript.

\section{References}

[1] Hao, J., Wu, Y., Fu, L., He, D. and He, K. (2001) Source Contributions to Ambient Concentrations of CO and NOx in the Urban Area of Beijing. Journal of the Environment Science and Health, 36, 215-228. https://doi.org/10.1081/ESE-100102619

[2] Markandeya, Pratap, D., Kumar, V. and Shukla, N.K. (2016) Seasonal Variation of Ozone in Industrial Area of Singrauli, India. Middle-East Journal of Scientific Research, 24, 11-14. https://doi.org/10.5829/idosi.mejsr.2016.24.01.22566 
[3] Kisku, G.C. and Markandeya (2015) Role of Air Pollutants Emitted from Coal Power Plant and Meteorology in Climate Change. Climate Change, 1, 483-490.

[4] Ali, M. and Athar, M. (2010) Dispersion Modeling of Noxious Pollutants from Thermal Power Plants. Turkish Journal of Engineering and Environmental Science, 34, 105-120.

[5] Cuculeanu, V., Sterrer, R., Mocioaca, G., Schimak, G. and Anghel, M. (2010) Design of the Air Quality Monitoring Network for Bucharest City. Romanian Reports in Physics, 62, 383-395.

[6] Balaceanu, C. and Stefan, S. (2004) The Assessment of the TSP Particulate Matter in the Urban Ambient Air. Romanian Reports in Physics, 56, 757-768.

[7] Giakoumi, A., Maggos, T.H., Michopoulos, J., Helmis, C. and Vasilakos, C.H. (2009) PM $_{2.5}$ and Volatile Organic Compounds (VOCs) in Ambient Air: A Focus on the Effect of Meteorology. Environmental Monitoring Assessment, 152, 83-95. https://doi.org/10.1007/s10661-008-0298-2

[8] ESS (Environmental Software and Services) (2002) Air Quality Modeling in Environmental Impact Assessment. Online Lecture on Air Pollution and Environmental Impact Assessment (AIR-EIA). http://www.ess.co.at/AIR-EIA/LECTURES/L001.html

[9] Tu, L.-K., Wu, Y.-L., Wang, L.-C. and Chang-Chien, G.-P. (2012) Monitoring and Dispersion Modeling of Polybrominated Diphenyl Ethers (PBDEs) in the Ambient Air of Two Municipal Solid Waste Incinerators and a Coal-Fired Power Plant. Aerosol and Air Quality Research, 12, 113-122.

[10] Bureau of Indian Standards, Government of India (2002) Criteria for Earthquake Resistant Design of Structures, IS 1893-Part 1: General Provisions and Buildings (CED 39: Earthquake Engineering). https://law.resource.org/pub/in/bis/S03/is.1893.1.2002.pdf

[11] Pandey, P., Patel, D.K., Khan, A.H., Barman, S.C., Murthy, R.C. and Kisku, G.C. (2013) Temporal Distribution of Fine Particulates $\left(\mathrm{PM}_{2.5}, \mathrm{PM}_{10}\right)$, Potentially Toxic Metals, PAHs and Metal-Bound Carcinogenic Risk in the Population of Lucknow City. Indian Journal of Environmental Science and Health, 48, 730-745. https://doi.org/10.1080/10934529.2013.744613

[12] Rutllant, J. and Garreaud, R. (1995) Meteorological Air Pollution Potential for Santiago, Chile: Towards an Objective Episode Forecasting. Environmental Monitoring Assessment, 34, 223-244. https://doi.org/10.1007/BF00554796

[13] Naik, S.M. (1992) Dispersion of Sulphur Dioxide around the Thermal Power Plant at Ahmadabad, India. Atmospheric Environment, 26, 331-338. https://doi.org/10.1016/0957-1272(92)90008-G

[14] Ko, F.W. and Hui, D.S. (2012) Air Pollution and Chronic Obstructive Pulmonary Disease. Respirology, 17, 395-401. https://doi.org/10.1111/j.1440-1843.2011.02112.x

[15] Sarath, K.G. and Bhola, R.G. (2012) Role of Meteorology in Seasonality of Air Pollution in Megacity Delhi, India. Environmental Monitoring Assessment, 184, 3199-3211. https://doi.org/10.1007/s10661-011-2182-8

[16] Bureau of Indian Standards. (2006) Revised National Ambient Air Quality Standards. Government of India. http://dmc.kar.nic.in/Pollution.pdf

[17] Nieuwenhuijsen, M.J., Basagaia, X., Dadvand, P., Martinez, D., Cirach, M., Beelen, R., et al. (2014) Air Pollution and Human Fertility Rates. Environment International, 27, 9-14. https://doi.org/10.1016/j.envint.2014.05.005

[18] Gianicolo, E.A., Mangia, C., Cervino, M., Bruni, A., Andreassi, M.G. and Latini, G. (2014) Congenital Anomalies among Live Births in a High Environmental Risk Area-A Case Control Study in Brindisi Southern Italy. Environmental Research, 128, 9-14. 
https://doi.org/10.1016/j.envres.2013.11.002

[19] Schembari, A., Nieuwenhuijsen, M.J., Salvador, J., De-Nazelle, A., Cirach, M., Dadvand, P. (2014) Traffic-Related Air Pollution and Congenital Anomalies in Barcelona. Environmental Health Perspective, 122, 317-323.

[20] Varon, J., Marik, P.E., Fromm, R.E. and Gueler, A. (1999) Carbon Monoxide Poisoning: A Review for Clinicians. The Journal of Emergency Medicine, 17, 87-93.

https://doi.org/10.1016/S0736-4679(98)00128-0

[21] Stanek, L.W., Sacks, J.D., Dutton, S.J. and Dubois, J.J.B. (2011) Attributing Health Effects to Apportioned Components and Sources of Particulate Matter: An Evaluation of Collective Results. Atmospheric Environment, 45, 5655-5663. https://doi.org/10.1016/j.atmosenv.2011.07.023

[22] Krishna, R., Reddy, M.K., Reddy, R.C. and Singh, R.N. (2004) Assimilative Capacity and Dispersion of Pollutants Due to Industrial Sources in Visakhapatnam Bowl Area. Atmospheric Environment, 38, 6775-6787. https://doi.org/10.1016/j.atmosenv.2004.09.014

Submit or recommend next manuscript to SCIRP and we will provide best service for you:

Accepting pre-submission inquiries through Email, Facebook, LinkedIn, Twitter, etc. A wide selection of journals (inclusive of 9 subjects, more than 200 journals)

Providing 24-hour high-quality service

User-friendly online submission system

Fair and swift peer-review system

Efficient typesetting and proofreading procedure

Display of the result of downloads and visits, as well as the number of cited articles

Maximum dissemination of your research work

Submit your manuscript at: http://papersubmission.scirp.org/

Or contact ojap@scirp.org 